\title{
Autobiographical Sketches (2021)
}

\section{Klaus Möbius ${ }^{1}$}

Received: 20 July 2021 / Accepted: 25 July 2021 / Published online: 12 August 2021

(c) The Author(s) 2021

\section{Abstract}

Klaus Möbius gives a selection of his biographical experiences which have shaped his academic and personal life.

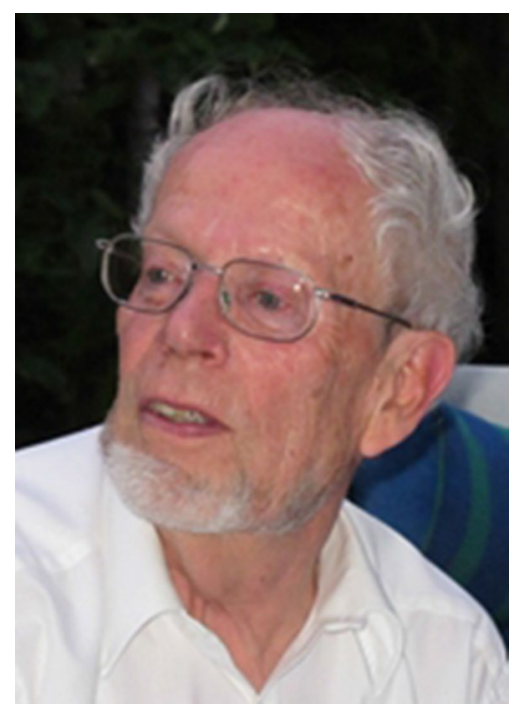

Better to become 85 than not to become 85 .

(old folk wisdom)

I was born in Berlin on June 4, 1936, between two disastrous historical events: in January 1933 by the seizure of power in Germany by Adolf Hitler, in September 1939 by the invasion of Poland by Nazi Germany. This was the

\section{Klaus Möbius}

moebius@physik.fu-berlin.de

1 Free University Berlin, Berlin, Germany 
beginning of World War II. My mother was an assistant in an antiquarian art and book store, my father an administrative officer in the Berlin division of a supra-regional bank. I was their second child, 2 years younger than my brother. My father had been severely wounded in World War I, he was limping which, fortunately, meant that he was not drafted as a soldier for World War II.

When in 1943/1944 the Allied air raids of Berlin became increasingly intense, the city authorities ordered mothers with small children to be evacuated to villages in the countryside. My mother and her two sons were moved to Grosswudicke, a small village about $90 \mathrm{~km}$ west of Berlin, but still on the eastern side of the river Elbe.

This location of our evacuation site later turned out to be rather unfavorable for us, the western side of the river Elbe would have been better. In addition, that has to do with Adolf Hitler and the last military contingent of the Wehrmacht, the Army Wenck. The freshly formed last German army consisted of the youngest soldiers of the Wehrmacht, many of them only inadequately trained. Army Wenck was to engage in the Battle for Berlin. Under Hitler's explicit orders, it was to liberate the "Reichshauptstadt" Berlin, which was being encircled by massive Soviet troops. However, since his army was not sufficiently armed for such an operation, General Wenck refused to carry out this "Führerbefehl".

Instead, in April/May 1945, the remains of the Army Wenck retreated from embattled Berlin and fled toward the river Elbe to surrender to US forces. The American troops had stopped on the west bank of the river, waiting for the Soviet troops to unite with them. But unfortunately, in the area around our village Grosswudicke, the Army Wenck clashed with strong Soviet and Polish combat units, they were well equipped with tanks and cannons. On May 4, 1945, there were heavy fights, also inside our village, with street and house fights, and hundreds of dead soldiers and civilians on that day. What an absurd and infernal slaughter that took place before the eyes of the horrified children!

Many civilians had tried to find shelter in the storage cellars of the farmhouses, including us with several other children screaming in fear. I remember that day very vividly, also the first Russian soldier rushing down the staircase of the cellar, searching for any hidden German soldiers, with their submachine gun ready to fire. But when they saw the screaming children, they calmingly shouted "Woyna kaput" and "Gitler kaput" ("War is over" and "Hitler is finished"). In addition, to have accomplished this ultimate goal, I remain forever grateful to them and their Allies. Two days later, on May 6, 1945, the survivors of the Army Wenck crossed the river Elbe at Tangermünde and went into American war captivity. In addition, 2 more days later, on May 8, 1945, Nazi Germany unconditionally surrendered to the Allies in Berlin-Karlshorst. In Europe, World War II was over.

Such a personal experience of war as a barely 9-year-old boy has accompanied me all my life, and has certainly contributed to my commitment for international cooperation and peace, against fascism and all forms of dictatorship. 


\section{School and University Training, Habilitation, Postdoctoral Stay in California: And Other Key Data of My Personal Life}

\subsection{School in East-Germany (Until 1952)}

There is nothing really worth mentioning about my elementary school days during our evacuation in Grosswudicke, except that all grades of the pupils were taught simultaneously in a single classroom by an old, but reactivated teacher. He was totally overburdened with his task and relied completely on the solidarity of his pupils. The older kids were asked to entertain the younger kids, and the city kids the village kids. This process worked quite well but, apparently, formal school teaching was falling behind. During the more than one year I spent at the village school, I did not really learn anything that I did not already know before, for instance from my parents or elder brother. But outside school, I did learn important things instead that helped me a lot later on; for instance, how to get enough wood from bombed house ruins around for heating and cooking at home. Or how to repair blown electrical fuses with inadmissible, but effective copper wires from power cords. Or how to find a viable solution for replacing my stolen bike in the general chaos of the victorious soldiers that were moving on. Or how to dismantle rifle ammunition and anti-aircraft grenades lying around and to collect the gunpowder inside and use it for small but thrilling fireworks. My brother and I got a lot of applause from the other children in the village for our exciting performances. But that was not the case with our parents and other adults. Nevertheless, these shows undoubtedly fueled my later affection for chemistry lessons at school and university with spectacular experiments for the viewers to enjoy.

In autumn of 1945 , our fortunately still complete family returned to our apartment in Berlin-Pankow that was undestroyed, now part of the Soviet Sector of Berlin. After a relaxing year in my old Pankow elementary school, I passed the entrance examination for a secondary school, the Carl von Ossietzky School, in Pankow in the fall of 1946. The first exciting thing there to happen was that the traditional segregation between boys and girls was quickly abolished. The teaching quality varied between "very good" (English) and "very bad" (Russian), with all grades in between for the other subjects. Nothing was really inspiring, I would say, except for the subject "Gegenwartskunde" (Contemporary Studies), i.e., World War II and post-war German history. Unfortunately, the freshly graduated junior teacher let his lessons degenerate into Stalinist propaganda and the glorification of the communist state party SED that ruled East-Germany (the German Democratic Republic, GDR). Naturally, such blatant indoctrination attempts challenged my contesting spirit, and also that of my closest school pal and friend, Dieter Piskol. Our comments in this regard did neither find approval with the teacher nor sympathy from our classmates, but this did not discourage us.

The conflict reached sort of a climax in spring 1952, when the principal of the Carl von Ossietzky School appeared in our classroom just in the moment when Gegenwartskunde was being instructed. He requested all of us (about 30 students) to stand up and commit ourselves to the GDR National Reconstruction Work for 
"voluntary reconstruction hours". Our task would be to help as unpaid auxiliary workers clear the heavily bombed "Grosse Frankfurter Strasse" (renamed "Stalinallee" in 1949) in East Berlin from the left-over wartime ruins. The SED party had decided, he said, to develop the Stalinallee into a magnificent boulevard following the Soviet models in Moscow. The reconstruction of the Stalinallee as an exceptionally wide magistral was the first major socialist prestige project in East Berlin to "demonstrate the superiority of socialism over capitalism, and to honor the great leader of the Soviet Union, Comrade Stalin".

All students of the class accepted this request for a commitment to "voluntary" reconstruction hours, with the exception of two students, Dieter Piskol and me. Our reasoning was that "voluntary" reconstruction hours simply means voluntary reconstruction hours, and thus, we should not be forced to them. The school director reacted first with disbelief, then with anger. He gave us a 1-day time to reconsider our decision to refuse a commitment.

Back at home, I told my parents about our action. They were not amused at all, they foresaw a lot of problems that were to come our way. Then my father said: Should I have made the refusal just for the pleasure of provoking the SED partyaffiliated school director, then I should better give in tomorrow. The price for such a pleasure of provoking would just become too high. But then he added: If, however, the apparent conflict between the director's words and actions is a matter of principle for me, then I should stand behind what I have done, no matter what the consequences will be.

Next morning, Dieter Piskol and I showed up at the principal's office. He sat in an armchair behind an imposing desk, and jovially said something like this: You certainly thought it over what you had said hastily yesterday. I am sure you now want to commit yourself to voluntary reconstruction hours. How many such hours do you have in mind? After a short pause, we uniso answered what we had previously agreed: 100,000 voluntary reconstruction hours (which, in our estimation, would take us well into retirement age).

The director's face turned dark red, he spiraled out of his armchair to unexpected height. Then he shouted: You are mocking socialism! And he expelled us from the Carl von Ossietzky School. He added that in future we would not be admitted to any other secondary school in the entire German Democratic Republic either. But then, after a long pause during which also we were left voiceless, he said that he will be generous and allow us to still finish the current 10th grade at Carl von Ossietzky School, i.e., to stay until September 1952. We were devastated, we had expected everything, but not school expulsion!

In addition, indeed, now the really big problems began for us. We had to find a secondary school in West Berlin that we could reach daily from our homes in East Berlin. In addition, where we would be able to take the Abitur (high-school graduation) in 3 years, including the subject Russian language (in West Berlin, French was usually the second foreign language). Fortunately, we found a suitable West Berlin secondary school, the Ranke Highschool, in the Berlin district Wedding, which borders the Pankow district. In reality, the way to school turned out to be very long because we had to cross the border between East Berlin and West Berlin twice a day, often with lengthy and bullying controls by the GDR border guards. 


\subsection{Escaping from East-Germany to West Berlin (1953)}

In March 1953, my parents decided to put an end to this nerve-wracking state of daily East-West commuting - and to illegally escape from the GDR ("Republikflucht", legal emigration was barred at that time). Escaping from the GDR meant to leave everything behind, to abandon friends and relatives. In addition, to be wanted by the East-German police in the entire GDR by means of their manhunt list. Therefore, Republikflucht was indeed a difficult decision to make. But we were lucky and reached West Berlin without border control, each family member at a different innercity check point. We never regretted our decision.

A new chapter of life began for us, with high-flying dreams of a wide world to travel to, with unimagined personal and social freedoms. But, at the same time, also with many initial difficulties, especially for my parents. But full of great options for the future, especially for my brother and me. We graduated from high school (my Abitur was in March 1955) and subsequently studied at the Free University of Berlin, my brother economics and marketing research, me physics, chemistry and mathematics. The deciding factor for my choice of studies was my teacher Dr. Günter Walther at the Ranke Highschool with his extremely inspiring instructions and the discussions that followed. I am still grateful to him. We became friends and stayed in contact over many years to come.

\subsection{The Building of the Berlin Wall (1961)}

There were many dates in the 1960s/1970s calendar that had a lasting impact on my personal and scientific life. Among the important ones were, for example:

In the early morning of August 13, 1961, armed GDR border police began building the Berlin Wall around West Berlin. Police and soldiers piled up concrete blocks to form barricades, erected barbed wire entanglements, and rammed in concrete posts-supervised by units of the GDR National People's Army. With the erection of the "anti-fascist protective wall", as the GDR officials called it, the SED leadership wanted to halt the increasing flow of refugees from the East to the West. In 1960, hundreds of thousands of people had fled from the GDR to the Federal Republic. The erection of the Berlin Wall not only divided Berlin into two hermetically separated hostile parts, East Berlin and West Berlin with the Iron Curtain between them, it also separated families and friends living in both parts of the city.

During that period, I graduated in Physics from the Free University Berlin (FUB) in 1962, received my Ph.D. in Physics in 1965, and habilitated in Experimental Physics in 1969.

My diploma project in the II. Physical Institute of FUB (1960/61) was about EPR spectroscopy on stable organic radicals. It was supervised by Professor Richard Honerjäger, who was an expert on vibrational-rotational microwave spectroscopy of diatomic molecules in the gas phase. Working there together with my study friend Erwin Klein, the first task of our diploma projects was to build an EPR spectrometer around an existing old electromagnet, using microwave spare parts from the 
institute's inventory. I am grateful to Erwin Klein for his essential contributions to build up the spectrometer. Especially, I thank him for getting me back on my feet after I had been knocked out by a gigantic electromagnetic discharge that I had caused by accidentally disconnecting the electromagnet from its power supply, the Institute's battery. In addition, I am grateful to Professor Honerjäger for giving me the freedom to apply our EPR spectrometer to large organic molecules in the solid state and study their g- and hyperfine-tensor components, a project far remote from the traditional research objects of his Institute.

I did my doctoral work on investigations of $\pi$-electron aromatic molecules with high-resolution electron spin resonance and polarography at the AEG Research Institute in Berlin-Reinickendorf. I thank Prof. Richard Honerjäger (FUB) for his encouraging interest in my work and Dr. Fritz Schneider (AEG Forschungsinstitut) for the generous provision of the most modern AEG-made high-resolution EPR spectrometer and NMR Gaussmeter as well as the polarography apparatus. In particular, I thank Dr. Schneider for our numerous committed, not infrequently controversial, discussions about science and society and their interrelated responsibilities. My special Thank You goes to my friend and colleague Martin Plato for his enlightening advice when I was running into quantum chemical problems-and for his support to solve them during the theoretical interpretation of the experimental data. My Ph.D. dissertation work was finally published in Zeitschrift für Naturforschung [1, 2] and won me the 1966 Karl Scheel Prize of the Berlin Physical Society.

\subsection{Marriage and Birth of Our Children}

My happiest moments in these years were the marriage with Uta in January 1964 and the birth of our daughters Katharina in March 1965 and Janina in April 1968. Uta became the main pillar in our family life, and our daughters added new dimensions of happiness and caring to our lives.

\subsection{Postdoctoral Year at the University of California, Riverside (1969/1970)}

Subsequently, also the year 1969/1970 was an extraordinarily happy and important year both for my personal and academic life. Together with my young family I spent a postdoctoral year in Southern California at Riverside. Coming from walled-in Berlin, we were overwhelmed by the sudden freedom for traveling, the incredible beauty and diversity of California: the breathtaking adventure of the deserts and mountains, the endlessness of the Pacific Ocean and the vast canyons of the Colorado River, the intact natural exoticism of the National Parks. In addition, all this so near to Riverside, and so easy to reach at weekends with our VW Beetle, sometimes with a tent, always with the indispensable water tank.

Supported by a Postdoctoral Fellowship of the Deutsche Forschungsgemeinschaft (DFG), I had chosen the laboratory of Professor August (Gus) Maki at the University of California (UC), Riverside. Since his years at Harvard as an Assistant Professor, Gus Maki was widely known for his pioneering work in EPR and ENDOR spectroscopy on organic transition-metal complexes in the solid state as well as on organic 
radicals in liquid solution. In 1964, he had moved to UC Riverside, starting as an Associate Professor, followed by a promotion to Full Professor in 1968. Gus wanted to continue work on radical-in-solution ENDOR, so he set up a high-power X-band ENDOR spectrometer at Riverside. He did not rely, however, on Varian Associates but rather on an assortment of surplus instruments around him. Robert Allendoerfer assisted him in this endeavor as a postdoc (1966-1968). Ultimately, they succeeded in obtaining well-resolved ENDOR spectra of radicals in solution. They developed a phenomenological theory to describe the dependence of the ENDOR enhancement factor on key parameters of the radical molecule, solvent environment and instrument $\mathrm{rf}$ and mw power capabilities that determine the delicate balance of the electron and nuclear relaxation and induced transition rates necessary to obtain continuous-wave (cw) ENDOR signals.

To learn from the experience Gus Maki had accumulated already on ENDORin-solution and to benefit from it for our own high-power ENDOR efforts at FUB which were still in the early stages, the Maki laboratory represented an ideal scientific environment for me. There I met Maki's postdocs Brian Moores and Hans van Willigen, a postdoc from the University of Nijmegen. Together we shared the fun and frustration to rebuild the dismantled ENDOR spectrometer which had been cannibalized after Robert Allendoerfer had left the Maki lab a year ago. Eventually, we found a solution to the huge stray field pick-up problems originating in the highpower radio frequency (rf) circuitry by properly shielding and grounding the dubious surplus devices - and by impedance matching the ENDOR coil of the microwave cavity through incorporating a California wine bottle (empty) in the rf circuitry wrapped with a few turns of heavy copper wire. Gus Maki was very pleased by our promising strategy of fighting stray field pick-up problems. In addition, suggested to promptly support this fight with a full bottle of Californian wine.

In addition, indeed, this impedance matching strategy enabled Hans van Willigen and me to jointly perform an elaborate ENDOR-in-solution study on the lifting of symmetry-based orbital degeneracy in large organic molecules by introducing weak unsymmetrical methyl-group perturbations. We chose pentaphenyl-cyclopentadienyl (PPCPD) radicals successively methyl-substituted at the para positions [3]. The solvents used were octane, pentane and isopentane above their melting points. The methylated PPCPD compounds were a generous gift by my friend Harry Kurreck from the Chemistry Department of FU Berlin. Over many years, we continued our close scientific and personal relations with Hans van Willigen; he became a frequent visitor of our group at FU Berlin where we did, together with Harry Kurreck and his co-workers from the Chemistry Department, joint ENDOR work on organic complexes as models for artificial photosynthesis.

There was another postdoctoral fellow in the Maki lab at Riverside, Christopher Winscom from the University of Sheffield, who later had a lasting impact on our scientific work at FU Berlin. Chris was involved in Gus's other key magnetic resonance activity, in optically detected magnetic resonance (ODMR) at zero magnetic field. Building up zero-field ODMR and even extending it to electron-nuclear double-resonance capability was a long and weary way to go. It needed the tenacity of Chris Winscom to eventually lead it to success. Like ENDOR-in-solution, zero-field ODMR had a rather sparse phase in Riverside around 1969, as far as new results were concerned; and 
Gus turned out to be not too patient with his postdocs. He gave us all a hard time in the demanding discussions with him, but we learned a lot from him. Robust, but scientifically sound responses to his criticisms were needed in this very provocative period to convince him that we were indeed on the right way to solve the instrumental problems. But when both ODMR and ENDOR-in-solution were ultimately rolling, Gus kept company with us in some long nights of experiments in an effort to cheer us up to get first signals before the coolants ran out. Rather frequently, such nights ended in Frank's bar in downtown Riverside for a game of pool, a beer and a bowl of chili. In addition, even the animating table dancing activities next to us could not stop our heated discussions about science, society, and the Vietnam war.

In the early 1970 s, Chris Winscom came to Berlin to work in my lab to join our efforts in setting up an ODMR spectrometer at zero magnetic field, using modern wideband microwave irradiation sources. What he had originally planned was to stay for a year, but his successful work in Berlin was extended several times up to almost 12 years. His exciting ODMR and ODNQR experiments on organic photoexcited systems have been a major part of our research activities and training of graduate students [4]. Thank you, Chris, these were exciting years with you!

\subsection{The Fall of the Berlin Wall (1990)}

For me and my family, the fall of the Berlin Wall in 1990 was the very highlight of the year and beyond, and the subsequent peaceful unification of East- and West-Germany was indeed widely considered as a paradigm shift to a better world to live in. The lifting of the Iron Curtain opened new horizons not only in global politics, for instance terminating the hard-line socialist party governments in Eastern Europe, but also changing completely our personal life. Finally, it became possible to do what was actually only the most obvious thing to do: to meet friends and family members from all-over Berlin who had been artificially separated from us West-Berliners for so many years. In addition, to meet EPR colleagues from East Berlin and East-Germany as well as friends from Eastern country laboratories, specifically from Poznan (e.g., Andrzej Szyczewski), Novosibirsk (e.g., Kev Salikhov, Renad Sagdeev, Yuri Grishin), Kazan (e.g., Kev Salikhov), and Moscow (e.g., Jakov Lebedev, Alexander Dubinskii). Organizing regular laboratory visits with them had previously only been possible by overcoming lengthy and tedious bureaucratic hurdles.

From the early time of this political paradigm shift, I vividly remember, for instance, that in June 1990, Gertz Likhtenshtein from the USSR Academy of Sciences in Chernogolovka, contacted me from East Berlin where he was staying at an agricultural institute of the GDR Academy of Sciences in Berlin-Wartenberg as a guest scientist. He was (and is) a very nice and rather unconventional Russian (now Israeli) colleague of mine, and he is a real humanist. Gertz asked me in a long-distance phone call (from East Berlin!) for an official invitation letter to enable him to apply for a short-term visa at the Soviet Embassy in East Berlin to visit me at the Free University in West Berlin. Since he had only three more days left to stay in East Berlin, I quickly figured out that there would be no chance to get such a visa for him in time. But we found a solution: 1989/1990 was time when the Berlin Wall was still standing but was just turning into a Swiss cheese, full 
of holes that were punched recently by the new species of "wallpeckers". We arranged a date for an unconventional encounter vis-a-vis such a hole in the Wall in Berlin-Kreuzberg, with which I was familiar in rather great detail. In addition, indeed, at the appointed hour, we came within sight of each other at the opposite sides of the hole in the Berlin Wall. In addition, when the patrolling East-German border soldier had his back turned to the hole, Gertz quickly wormed his way into West Berlin. After half a day of exciting excursions and discussions together, he happily returned to East Berlin-worming his way through the same hole, now in opposite direction. A rather unusual approach to international scientific exchange!

\section{Research Projects and International Cooperations}

My EPR Lab at the FUB, which in a few years had developed from a patchwork of spare parts from the Institute into an internationally respected laboratory for multiple-frequency multiple-resonance EPR spectroscopy, was generously supported by research grants from several foundations, primarily by the Deutsche Forschungsgemeinschaft (DFG). The laboratory attracted not only highly talented students and post-graduated scientists, but was also an esthetic and visual delight. This was also true, for example, for the young artist Solweig v. Kleist, a girl friend of one of our PhD students. In 1982, she created a series of copper engravings with impressions from our laboratory; she amended each image with a quotation from Johann Wolfgang Goethe's Faust I (see below).

Alas! In this prison must I stick? This hollow darkened hole of brick... Faust I (Goethe)

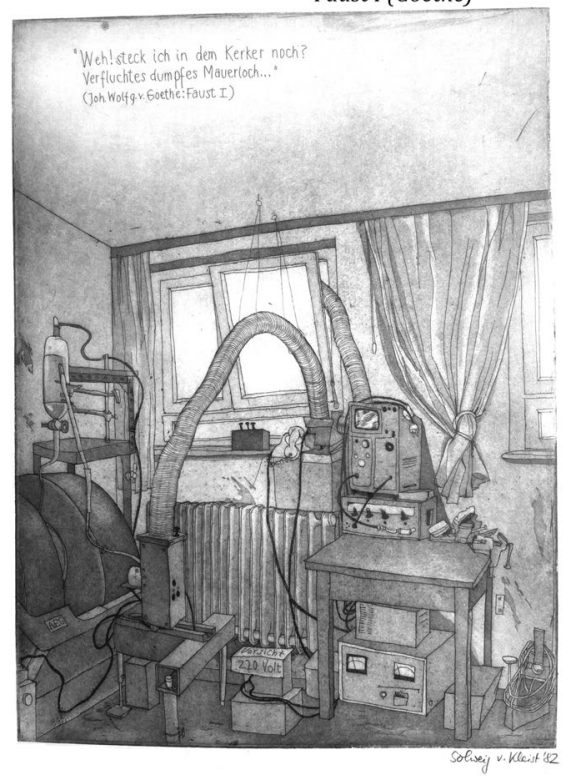

The wild peaks with their deep clefts, Would cease to bar my godlike way... Faust I (Goethe)

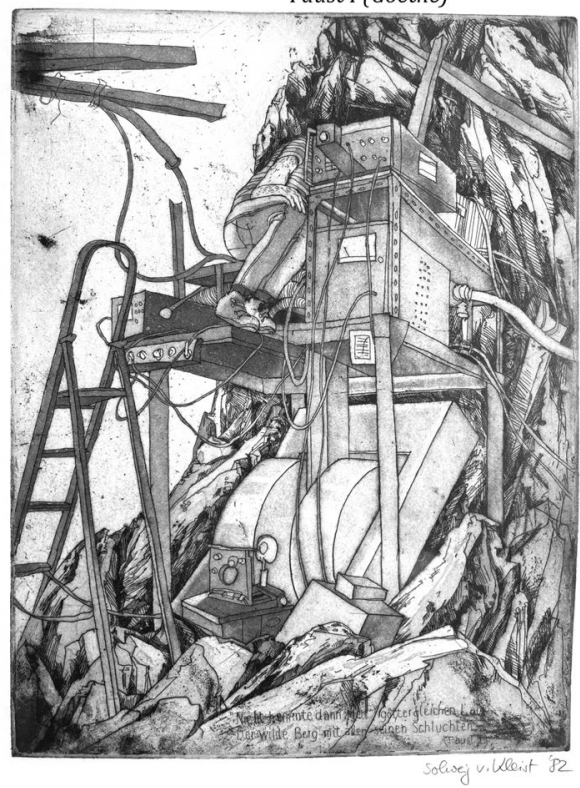


Over the years, our research was stimulated by our frequent interactions with eminent EPR spectroscopists from German and foreign laboratories from which often personal friendships developed. Just as examples of such friendships, I want to mention Harry Kurreck from the Chemistry Department of FU Berlin, Gus Maki from UC Riverside, Jack Freed from Cornell, Renny Fields from Cornell, George Feher from UC San Diego, Mel Klein from UC Berkeley, Dietmar Stehlik from the Physics Department of FU Berlin, Giovanni and Giorgio Giacometti, Pier-Luigi Nordio, Carlo Corvaja and Marina Brustolon from Padova, Kev Salikhov from Kazan, Yuri Grishin and Elena Bagryanskaya from Novosibirsk, Fabian Gerson and Günther Rist from Basel, Yakov Lebedev and Sasha Dubinskii from Moscow, Jürgen Hüttermann from Regensburg, Heinz-Jürgen Steinhoff from Osnabrück, Haim Levanon from Jerusalem, Jack Fajer from Brookhaven, Daniella Goldfarb from Rehovot, Arnold Hoff, Jan Schmidt and Edgar Groenen from Leiden, Seigo Yamauchi from Sendai, Giovanni Venturoli from Bologna, Alexey Semenov from Moscow, and Wolfgang Lubitz from Mülheim.

At this point, I would like to make a special reference to three colleagues from the FU Berlin and personal friends of mine who unfortunately passed away much too early, but who were of central importance for our interdisciplinary scientific projects: Reinhard Biehl (1944-1987), since the mid 1980's at Bruker Biospin), Dietmar Stehlik (1939-2007), Physics Department) and Harry Kurreck (1932-2015), Chemistry Department). I still miss their friendship and support very much.

This statement also applies to my international friends and colleagues who have meanwhile passed away. I still mourn for the much too early gone Yakov Lebedev (1935-1996), Pier-Luigi Nordio (1936-1998), Mel Klein (1921-2000), Arnold Hoff (1940-2002), Gus Maki (1930-2008), Seigo Yamauchi (1948-2012), Haim Levanon (1938-2014, George Feher (1924-2017). They remain remembered. My consolation is the Jewish proverb: The only truly dead are those who have been forgotten.

International collaboration in research projects was - and still is - at the center of my academic life and interest. That is why I consider extended stays at laboratories in foreign countries as important benchmarks of my life-from which often lifelong friendships developed. Examples of such stays are: Postdoctoral Research Fellow (German Research Foundation, DFG) at UC California Riverside (Gus Maki, 1969/70); Visiting Professor (DFG) at the Hebrew University of Jerusalem (Haim Levanon, Summer 1980), Visiting Professor (German Academic Exchange Service, DAAD) at the Indian Institute of Technology Madras (Subu Subramaniam, Winter 1983), Visiting Professor at the University of Padova (Pier-Luigi Nordio, Giovanni Giacometti, Winter 1997), Fellow of the Institute for Advanced Studies of the Hebrew University of Jerusalem (Haim Levanon, Winter 1990/91), Visiting Professor at the Tohoku University (The Japan Society for the Promotion of Science, JSPS), Sendai (Seigo Yamauchi, Spring 2001), Roessler Lecturer at the Cornell University, Ithaca (Jack Freed, 2001), Fellow of the Institutes for Advanced Studies of the University of Bologna (Giovanni Venturoli, Stefano Ciurli, Winter 2009 and Winter 2010).

Currently, our (bio)chemically and (bio)physically oriented research activities are focused on organic electron transfer systems such as those enabling Photosynthesis. This is the most important process for Life on Earth. It provides all the oxygen we breathe, all the food we eat and all the fossil fuels we burn for our civilization. Understanding the 
underlying physical, chemical and biological principles of photosynthetic solar energy conversion and sustainable storage is among the grand challenges under the threat of global climate change. Over the years, we have been studying light-induced transport processes of electrons and ions in artificial photosynthesis donor-acceptor complexes as well as membrane-bound protein complexes, for example Reaction Centers from photosynthetic bacteria and plants. In doing so, we employ modern methods of cw and pulsed EPR spectroscopy and its multi-frequency, multi-resonance variants, such as electron-electron double (ELDOR) and electron-nuclear double and triple resonance (ENDOR, TRIPLE), in particular at high magnetic fields, as well as fast optical absorption spectroscopy. By combining EPR and optical spectroscopies, we cover a wide timescale of photochemical reactions, ranging from tens of femtoseconds to tens of seconds. The research activities were (and are) performed in collaboration with scientists from Germany, Italy, Russia, USA, Israel, Japan, The Netherlands and Poland. The spectroscopic data are analyzed by state-of-the-art quantum chemical methods to determine the electronic and geometrical structures (distances and orientations) of those molecules that are involved in the biological process, including their conformational changes during the light-driven reaction. In this context, our co-worker Martin Plato has to be praised as a very competent and indispensable member of our group as a Senior Scientist-he always was (and is) the main pillar of the theoretical efforts in our group and a dear friend of all of us.

In addition, at this point, I would like to highlight also Kev Salikhov from Novosibirsk and Kazan. He is our long-time cooperation partner in the theory of spin dynamics of photoexcited radical-pair complexes in photosynthesis and biomimetic model systems. In addition, he was and still continues to be a stimulating partner in the discussion of the experimental possibilities to detect the effects of spin polarization by unconventional pulse EPR techniques.

Along with these research activities, we have cultivated a long and successful tradition in magnetic resonance instrumentation development. Dominant examples are project-adapted stationary cw ENDOR-in-solution and TRIPLE-in-solution spectroscopies as well as pulsed EPR, ENDOR, ESEEM, ELDOR and ELDORdetected NMR methods at standard X-band microwave frequency/magnetic field values, later at high magnetic fields and microwave frequencies, e.g., at $3.5 \mathrm{~T}$ and $95 \mathrm{GHz}$ (W-band), see [5]. In the long-term endeavor of developing high-field/highfrequency EPR spectrometers, our cooperations with Yakov Lebedev and Alexander Dubinskii from Moscow and Yuri Grishin from Novosibirsk have been of great importance over the years for the success of the demanding high-field projects. In addition, the open exchange of ideas, experiences and recent developments in highfield, high-frequency EPR and ENDOR instrumentation development with Daniella Goldfarb from the Weizmann Institute in Rehovot, Israel, has always been very valuable to us and highly appreciated by us, see [6]. 
I feel you float around me, Spirit, I summon to appear, speak to me! Faust I (Goethe)

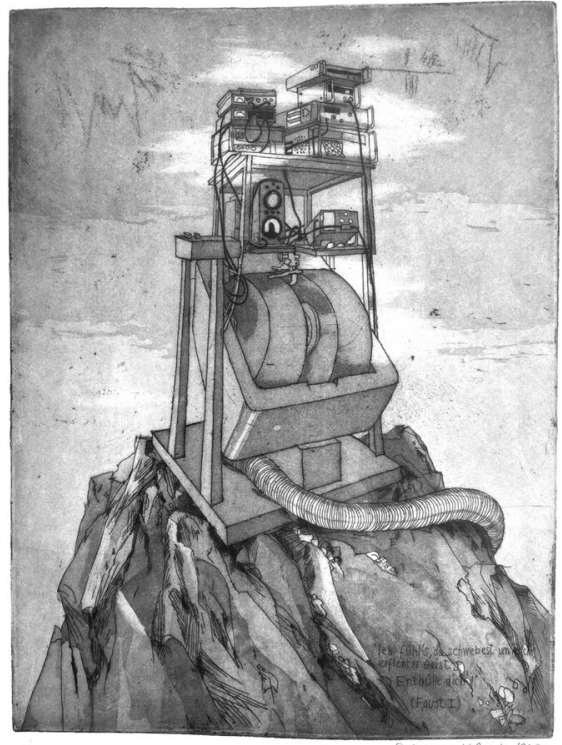

Faust: A knock? Enter! Who's plaguing me again? Mephistopheles: I am

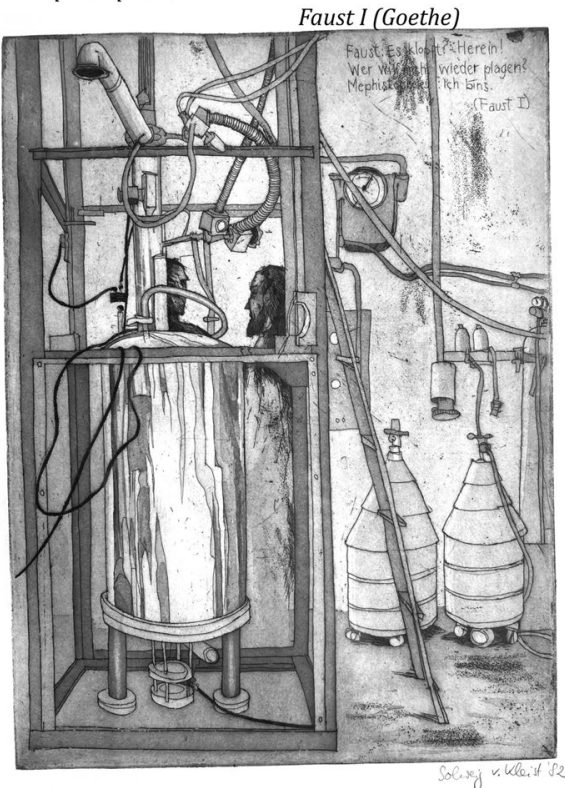

My research group at the FU Berlin has been blessed over the years with highly talented and motivated undergraduate and graduate students-as well as by excellent postdoctoral collaborators, they have become driving forces in our EPR instrumentation development and novel applications. I am deeply indebted to all of them. Most notably, I mention here (in almost chronological order): Klaus-Peter Dinse, Reinhard Biehl, Winfried Kaminski, Edwin Boroske, Lothar Mayas, Christian von Borczyskowski, Wolfgang Lubitz, Chris Winscom, Edmund Haindl, Olaf Burghaus, Friedhelm Lendzian, Martin Rohrer, Robert Klette, Jens Törring, Jenny Schlüpmann, Petra Jaegermann, Martina Huber, Vera Hamacher, Anna Toth-Kischkat, Burkhard Endeward, Volker Weis, Gordon Elger, Marilena DiValentin, Werner Fröhling, Edlev Bergmann, Moritz Knüpling, Martin Fuchs, Michael Fuhs, Wolfgang Möhl, Chris Kay, Anton Savitsky, Thomas Prisner, Stefan Weber, and Alexander Schnegg.

I want to emphasize that important contributions to the instrumental and methodological developments also came from the numerous undergraduate students (about 70 in total) who usually worked closely with graduate students and senior scientists assigned to them in our group.

\subsection{Light-Driven Primary Charge Separation in Photosynthesis}

I was introduced to photosynthesis by Arnold Hoff from the University of Leiden. It happened during an EPR symposium in Nijmegen that was organized by Bert 
de Boer in the hot August of 1976. I had given a lecture on our ENDOR experiments on large organic radicals in liquid solution, and the spectra showed an impressive resolution of many hyperfine lines. Arnold Hoff was in the audience. He had recently returned to Leiden from George Feher's lab in San Diego, where he had been working as a postdoc, to accept a position as senior research scientist at the Department of Biophysics at Leiden University. There, he continued his research on the structure and function of photosynthetic complexes at low temperatures applying a combination of magnetic resonance and optical techniques. Arnold invited me to a nearby pub for a cold beer. Over that glass of beer Arnold introduced me-with obvious enthusiasm - to the beauties of photosynthesis, in particular to the lightinitiated first electron transfer steps for charge separation across the photosynthetic membrane. In addition, over another glass of beer, we discussed the possibility of doing joint ENDOR-in-solution experiments on the electron transfer cofactors in bacterial photosynthesis. In addition, we were both excited about the collaboration that was starting to brew. And, we realized our plans.

During Arnold's first visit to my laboratory in Berlin (it was close to the white Christmas of 1976 and bitterly cold) we could indeed record the first nitrogen and proton ENDOR and TRIPLE spectra of the bacteriochlorophyll cation radicals in fluid organic solvents. Most of the nitrogen and proton hyperfine couplings, including their signs, could be measured and assigned. Within a year, Arnold and I wrote our first joint paper of the results, submitting it to PNAS. It was communicated by George Feher in February 1978 and published in May [7]. This was exciting and promising for the next step to do: ENDOR-in-solution on the cofactor cation and anion radicals generated in the illuminated integral membrane protein complex of the reaction center (RC) of photosynthetic bacteria. Undoubtedly, an ambitious project! After all, the RC is a protein complex with a molecular weight of more than $100 \mathrm{kDa}$.

This promise could actually be realized. In addition, Arnold Hoff was again our cooperation partner. But I should not forget to emphasize that first we needed a trusted source of reaction center protein preparations to do ENDOR on them. In addition, it was Maibi Michel-Beyerle at the Technical University Munich who catalyzed my encounter with Hugo Scheer from the Ludwig-Maximilian University in Munich. And it was Hugo Scheer who provided the excellent preparations of reaction center protein solution for our liquid-phase ENDOR experiments. A long-lasting cooperation started between our groups, very fruitful, very enjoyable. And very enlightening - not only in terms of structural biology and magnetic resonance but also in terms of environmental issues, twentieth century history, and international cooperation, in particular with Israel. All in all, the ENDOR-in-solution experiments on photosynthetic reaction center proteins took 10 more years before the final results were published, for instance in a 1988 paper, with Friedhelm Lendzian, Wolfgang Lubitz, Hugo Scheer, Arnold Hoff, Martin Plato, Eberhard Tränkle and me as coauthors [8].

These studies may be useful for a better understanding of photosynthesis beyond bacterial organisms, be it plants or even artificial donor-acceptor systems that mimic solar energy conversion in photovoltaic devices. 
In terms of the structure-function relationship in photosynthesis, some fundamental problems remained unresolved, for example: What are the most important controlling factors of the high quantum yield of the light-initiated (primary) longrange electron transfer (ET) chain in natural Reaction Centers? The complexity of the natural RC has prompted worldwide studies of simpler model systems that might reproduce essential features of the biological target. In the mechanistic approach, one seeks to reproduce, in tailor-made donor-spacer-acceptor complexes, the electronic states associated with basic features of charge separation and charge-recombination in photosynthesis. In this endeavor, time-resolved EPR and transient-absorption studies of model systems represent an active field of research. These studies combine creative work in chemical synthesis with advanced methods of fast EPR and optical spectroscopies.

\subsection{Biomimetic Model Systems of Photosynthesis}

We start this section with photosynthetic model systems in their doublet, triplet and radical-pair states to elucidate their static and dynamic properties. Our time-resolved EPR studies were shaped by the intensive collaboration with the working groups of Harry Kurreck of the Department of Chemistry of the FU Berlin, Haim Levanon of the Department of Physical Chemistry of the Hebrew University of Jerusalem and Seigo Yamauchi of Department of Chemistry of the Tohoku University in Sendai. The results are summarized, for instance, in the following review papers [9-11].

In the collaboration with Seigo Yamauchi and his co-workers, X- and W-Band time-resolved EPR (TREPR) studies on radical-excited triplet pairs (RTPs) between metallo-tetraphenyl-porphyrins (for instance MgTPP, ZnTPP) and axial-ligating nitroxide radicals in fluid solution were performed. Chemically induced dynamic electron spin polarization (CIDEP) effects were exploited to determine the spin multiplicities of the transient states involved in the light-pulse initiated photo-process. From the analysis of the spin polarization patterns, an exchange interaction between the triplet porphyrin and the nitroxide radical was found to be ferromagnetic or antiferromagnetic depending on the type of substitution of the nitroxide radical.

Unlike the natural photosynthetic system, in which the chromophores are not covalently bound to each other, most of the donor-spacer-acceptor model complexes are covalently linked molecules. More recently, however, examples of hydrogenbonded DA system, held together by Watson-Crick base-pairing interactions have been studied [10]. Although these model systems cannot serve as ultimate mimics for photosynthesis, their main value is in clarifying the nature of intermolecular ET in complex systems in terms of the thermodynamic and molecular parameters, including the weak interaction with the environment and their large consequences on their function. At this point, I want to emphasize the important role of our collaboration partner Kev Salikhov from Kazan in guiding the theoretical analysis of the transient spin polarization effects observable in the TREPR spectra of the spincorrelated radical-pairs (SCRPs) generated by the primary light excitation pulses. 


\section{ENDOR-in-Solution on the Primary Donor $P_{865}^{++}$of Photosynthetic Bacterial Reaction Centers}

In the following, we briefly summarize a key example of our cw ENDOR and electron-nuclear TRIPLE resonance studies in solution and single crystals of the primary donor dimer $\mathrm{P}_{865}$ in the $\mathrm{RC}$ of the purple bacterium Rhodobacter $(R b$.) sphaeroides at physiological temperatures; this work was performed partly in collaboration with George Feher and his co-workers at UC San Diego [12].

The primary processes of photosynthesis provide a "Garden of Eden" for the EPR spectroscopists because in each electron transfer step a transient paramagnetic intermediate is formed. The comparison of the frozen-solution EPR spectra of monomeric $\mathrm{BChl}^{\circ+}$ in an organic solvent and $P_{865}^{\cdot+}$ in the RC revealed a striking difference in the linewidth of both EPR spectra: for the primary donor $P_{865}^{\bullet+}$, it is $1 / \sqrt{2}$ narrower than for $\mathrm{BChl}^{\bullet+}$ [13].

This observation was explained earlier by Norris, Katz and co-workers at Argonne by the "special pair" hypothesis, i.e., the unpaired electron of $P_{865}^{\bullet+}$ is equally shared between the two halves of a (BChl $a)_{2}$ dimer cation radical, which they assumed to be symmetric. Feher, Hoff and co-workers at San Diego confirmed the dimeric nature of $P_{865}^{\bullet+}$ by comparing the ENDOR spectra of frozen-solution sam-

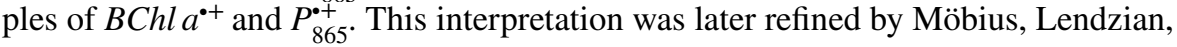
Lubitz and their co-workers for RCs in fluid solution under physiological conditions by taking advantage of the high spectral resolution of ENDOR-in-solution. From the highly resolved hyperfine structures of the monomers and dimers and their analysis by Martin Plato's by all-valence electron MO methods (RHF-INDO/SP), it was concluded that the primary donor dimer has to be viewed as a super-molecule with the wave function extending over both dimer halves. Moreover, the symmetry of the electron spin density distribution over the two dimer halves is broken favoring the $\mathrm{L}$ half, on the average, by $2: 1$. Final assignments of the hyperfine coupling constants resulted from site-specific deuteration and ${ }^{15} \mathrm{~N}$ labeling as well as investigations of $P_{865}^{\bullet+}$ in RC single crystals. The analysis shows an asymmetric spin distribution in favor of $P_{A}$, the BChl dimer half bound to the L subunit $\left(\rho_{A}: \rho_{B} \approx 2: 1\right)$. Thus, it is manifested that the "special pair" is also electronically an asymmetric dimer.

It has been discussed that such an asymmetry in the electronic structure of $P_{865}^{\bullet+}$ might represent an important functional factor in controlling the vectorial properties of photosynthetic electron transfer, such as the high quantum yield. No surprise, therefore, that the "unidirectionality enigma" of electron transfer along the specific protein branches, like in bacterial RCs and Photosystem I and II, is still vividly discussed. The single-crystal ENDOR and TRIPLE work on $R b$. sphaeroides RCs at physiological temperatures, which were performed independently by three groups, G. Feher and co-workers at UC San Diego, W. Lubitz and co-workers at TU Berlin, K. Möbius and co-workers at FU Berlin, but were ultimately published jointly in a "milestone paper" [12].

This publication represents a culmination of 2 decades of EPR work on the primary donor in bacterial RCs. Subsequently, similar ENDOR studies were performed 
on the primary donor radical cations, $P_{700}^{\bullet+}$ and $P_{680}^{\bullet+}$, in the reaction centers of oxygenic photosynthesis, Photosystem I and Photosystem II.

\subsection{High-Field EPR on Nitroxide Spin-Labeled Bacteriorhodopsin, the Light-Driven Proton Pump}

Photosynthesis, the strategy to harvest sunlight as energy source for synthesizing ATP (adenosine triphosphate, the universal energy carrier in biological cells) has been invented by Nature twice: $(i)$ In the photosynthetic reaction center (RC) protein complexes of certain purple bacteria, cyanobacteria and plants; this process is initiated by light-induced primary electron transfer between chlorophyll and quinone cofactors and mediated by the protein micro-environment. (ii) In the Bacteriorhodopsin (BR) protein complex; this process is set going by light-initiated primary proton transfer between amino acid residues and mediated by conformational changes of the only cofactor, the retinal. We employed site-directed mutants of spinlabeled organisms with attached nitroxide spin probes for EPR studies of structure and dynamics of the molecular complexes.

In this section, we briefly summarize our spin-label high-field EPR work on paradigmatic proton transfer proteins such as bacteriorhodopsin. BR is a $26 \mathrm{kDa}$ protein complex located in the cell membrane of halophilic archaebacteria. This work was performed in close cooperation with Heinz-Jürgen Steinhoff and his co-workers at the University of Osnabrück. The aim was to obtain new insights concerning the molecular mechanisms of light-driven proton transfer, in particular by probing sitespecifically the local polarity and proticity values along the proton channel in proteins embedded in functional membranes. We focused on proton transfer intermediates of selectively nitroxide (MTS) spin-labeled BR mutants from Halobacterium (H.) salinarium to determine potential barriers and molecular switches for vectorial transmembrane proton transfer.

Seven transmembrane helices $(A-G)$ enclose the retinal chromophore that is covalently attached to the amino acid lysine, K216 on helix G, via a protonated Schiff base. Absorption of $570 \mathrm{~nm}$ photons initiates the all-trans to 13-cis photoisomerization of the retinal. The Schiff base then releases a proton to the extracellular medium and, subsequently, is re-protonated from the cytoplasm. During this catalytic photocycle, transient intermediates are formed with conformational changes of the protein and the retinal. They are suggested to function as a "re-protonation switch". Such changes ensure that release and uptake of protons do not proceed from the same side of the membrane, but rather enable BR to work as a vectorial transmembrane proton pump.

By $95 \mathrm{GHz}$ high-field EPR studies, in which Anton Savitsky of our group and Christoph Wegener of the Steinhoff group played a leading role, details of the polarity profile along the putative proton channel were probed by g- and hyperfine-tensor components from a series of 10 site-specifically nitroxide spin-labeled BR mutants, with MTS spin label as the reporter side chain R1 [14]. The $\mathrm{A}_{\mathrm{zz}}$ component of the ${ }^{14} \mathrm{~N}$ hyperfine-tensor of $\mathrm{R} 1$ and its $\mathrm{g}_{\mathrm{xx}}$ component of the g-tensor are particularly sensitive probes of the micro-environment of the nitroxide side chain R1. They 
allow to measure changes in polarity and proticity of the protein, in other words: $\mathrm{g}_{\mathrm{xx}}$ and $\mathrm{A}_{\mathrm{zz}}$ probe the local electric fields and the availability of $\mathrm{H}$-bond forming partners of nearby aminoacid residues or water molecules. When the magnitude of the tensor elements $\mathrm{A}_{\mathrm{zz}}$ and $\mathrm{g}_{\mathrm{xx}}$ of the spin labels are plotted as function of the nitroxide location in the transmembrane protein, the plots directly reflect the hydrophobic barrier that the proton has to overcome on its way through the protein channel.

In our high-field EPR studies on nitroxide spin-labeled bacteriorhodopsin, our long-standing cooperation with Edgar Groenen and his co-workers at the University of Leiden was very much to the benefit also of this project. This is demonstrated, for instance, in our joint publication from 2014 [15]. On the basis of EPR experiments at $275 \mathrm{GHz}$, the dependence of the cw EPR spectra of nitroxide spin-labeled protein sites in sensory- and bacteriorhodopsin on the micro-environment were considered. The high magnetic field provides the Zeeman resolution necessary to disentangle the effects of hydrogen bonding and polarity. In the $\mathrm{g}_{\mathrm{xx}}$ region of the $275 \mathrm{GHz} \mathrm{EPR}$ spectrum, bands are resolved that derive from spin-label populations carrying no, one or two hydrogen bonds. The $\mathrm{g}_{\mathrm{xx}}$ value of each population varies hardly from site to site, significantly less than deduced previously from studies at lower microwave frequencies. The fractions of the populations vary strongly, which provides a consistent description of the variation of the average $\mathrm{g}_{\mathrm{xx}}$ and the average nitrogen-hyperfine interaction $\mathrm{A}_{\mathrm{zz}}$ from site to site. These variations reflect the difference in the proticity of the micro-environment, and differences in polarity contribute marginally. Concomitant $95 \mathrm{GHz}$ ELDOR-detected NMR experiments on the corresponding nitroxide in perdeuterated water resolve population-specific nitrogen-hyperfine bands, on which the interpretation is based for the proteins.

Such multi-group cooperation projects need a lot of support from outside. In this example, we are grateful to Herbert Zimmermann (Max-Planck Institute for Medical Research, Heidelberg) who kindly provided the nitroxide side chain R1. We acknowledge financial aid by the Netherlands Organization for Scientific Research (NWO) and the Deutsche Forschungsgemeinschaft (DFG).

\subsection{Soft-Glass Matrix Interactions with Proteins: Life Without Water}

Recently, our main goal of the research projects on structure-dynamics-function relationships in photosynthesis has shifted to the role of subtle matrix effects on the cofactors for the biological function. In particular, we are interested in the weak and complex hydrogen-bond interactions between nanoscale protein molecules and soft sugar-glass matrices in which they are embedded. Specifically, we are interested in embedding photosynthetic reaction centers proteins in dehydrated trehalose sugar glasses at elevated temperatures to study the phenomenon of anhydrobiosis, i.e., life without water in hot and dry climate areas. The cooperation partners of this research project are Giovanni Venturoli and his co-workers Francesco Francia and Marco Malferrari (Bologna), Alexey Semenov and his co-worker Mahir Mamedov (Moscow), Kev Salikhov (Kazan), Klaus Möbius (Berlin), Anton Savitsky (Dortmund) and Wolfgang Lubitz (Mülheim). 
We just published a summary of the present status of our high-field EPR and fastlaser studies on the soft dynamic confinement of membrane proteins by dehydrated trehalose matrices as a joint progress report of all the key participants involved [16].

It is common knowledge that water is an essential component of life, primarily to ensure metabolism; the vast majority of organisms will die upon complete drying. However, several organisms, such as resurrection plants, rotifers, and tardigrades, have developed in evolution the ability to withstand a severe water deficit in any phase of their life cycle. These species (anhydrobiotes), upon removal of intracellular water, survive as desiccated material, entering a state of suspended life. The period of arrested animation and metabolism can last as long as decades, or centuries, and, when normal water availability is restored in the environment, they resume metabolic activity and life. Anhydrobiotes are distributed among the three domains of life - archaea, bacteria, and eukaryotes.

Studies of anhydrobiosis go hand in hand with investigations of the molecular regulation mechanisms of electron- and proton transfer processes under extreme environmental conditions, such as dryness and heat. During the last few decades, sugar-glass matrices have attracted a growing interest not only in the food-storage industry but also in the biotechnology community for their ability to stabilize labile proteins against external stress. A prominent example of such sugar-glass matrices is the disaccharide trehalose ( $\alpha$-D-glucopyranosyl $\alpha$-D-glucopyranoside). Upon dehydration, it forms already well above room temperature soft-glass matrices that protect the hosted protein against denaturation. In addition, this without the cellular damages that are typically induced by conventional freezing, heating, and drying protocols.

In our research project, we performed W-band high-field EPR and fast-laser studies on disaccharide matrix effects on structure and dynamics of donor-acceptor protein complexes related to photosynthesis, including the non-oxygenic bacterial Reaction Center (RC) and the oxygenic RCs Photosystem I (PS I) and Photosystem II (PS II).

To clarify the molecular mechanisms of disaccharide bioprotection, structure and dynamics of sucrose and trehalose matrices at different controlled hydration levels were probed by perdeuterated nitroxide spin labels and native cofactor intermediates in their charge-separated states. It is concluded that dry trehalose operates as anhydrobiotic protein stabilizer by means of selective changes in the first solvation shell of the protein upon trehalose-matrix dehydration with subsequent changes in the hydrogen-bonding network.

Such changes usually have an impact on the global function of a biological system. By means of pulsed W-band high-field multi-resonance EPR spectroscopies, such as ELDOR-detected NMR and ENDOR, in conjunction with using isotope labeled water $\left(\mathrm{D}_{2} \mathrm{O}\right.$ and $\left.\mathrm{H}_{2}{ }^{17} \mathrm{O}\right)$, the biologically important issue of sensing and quantification of local water in proteins is addressed. Indeed, to finally understand the role of trehalose matrices as a strategy to survive prolonged periods of drought in the global warming scenario of the looming climate change may develop perhaps into an intriguing lesson from Nature. 


\subsection{The Möbius-Strip Topology in Chemistry: Hückel Aromaticity Versus Möbius Aromaticity}

We now come to our youngest research project, Möbius/Hückel topology switching, which to realize was again only possible through international cooperation, this time through collaboration with Lechosław Latos-Grażyński and his co-workers at the University of Wroclaw (Poland).

To twist a Hückel-type aromatic ring molecule into a Möbius-type aromatic ring is still a major challenge of synthetic chemistry. For a chemical synthesis, there must be an inherent driving force in the synthesis strategy that induces or stabilizes the $180^{\circ}$ twist of a Möbius strip. Edgar Heilbronner at the University of Basel had courageously predicted in 1964, on the basis of simple Hückel Molecular Orbital (HMO) theory, that sufficiently large [n]annulenes (n integer number) with a closed-shell electron configuration of $4 \mathrm{~N} \pi$-electrons should allow for sufficient $\pi$-conjugation stabilization (i.e., $\pi$-aromaticity) to compensate too much steric strain. Hence, Möbius aromatic molecules should be synthesizable when using smart synthesis strategies. For this, in the multistep synthesis procedure one has to introduce a stable $180^{\circ}$ phase change of their carbon $2 \mathrm{p}_{\mathrm{z}}$ orbitals by twisting their hydrocarbon skeleton from Hückel into Möbius topology.

It lasted 40 years, until 2003, when the first synthesis of an aromatic Möbius annulene was accomplished by Rainer Herges and co-workers at the University of Kiel. And it took another four years before, in 2007, Lechosław Latos-Grażyński and co-workers at the University of Wroclaw succeeded in synthesizing a new type of expanded porphyrin compound that can adopt Möbius topology. Upon changes of solvent and temperature, the molecular topology can dynamically switch between Hückel and Möbius conjugation.

In our cooperation project, we used EPR and ENDOR spectroscopy in fluid solution at variable temperatures to study the cation radical open-shell system of the expanded porphyrin di-p-benzi[28]hexaphyrin to elucidate the electronic structure and spin density distribution.

In 2015, we published our first joint paper of the two groups on Möbius-Hückel topology switching in an expanded porphyrin cation radical [17]. In 2016, the work was extended in our group by Martin Plato to include novel DFT quantum chemical calculations on photoexcited triplet open-shell hexaphyrin systems [18].

The concept of Möbius topology as a stabilizing factor for aromaticity in expanded organic molecules has gained strong momentum in recent years from quantum chemistry theory on such systems employing large-scale calculations up to the level of modern DFT. A dynamic switching between Hückel and Möbius topologies with different electronic structures and properties by applying only small changes in external conditions (temperature, solvent, $\mathrm{pH}$ ) or ring structure (meso substituent, central metal), belongs to the most appealing applications of [28] hexaphyrins. If properly controlled, molecular switches with unique optical and magnetic properties can thus be generated. In fact, hexaphyrin-type expanded porphyrins have already been approved as promising building blocks for switchable Hückel-Möbius complexes to be used as novel nonlinear optics devices. This is because Möbius and Hückel conformers exhibit large differences in their pronounced nonlinear optical 
properties. To conclude this section, I refer to our new book "The Möbius Strip Topology: History, Science and Applications in Nanotechnology, Materials, and the Arts" by Klaus Möbius, Martin Plato and Anton Savitsky [19].

\section{Academic Career}

After the habilitation at Free University of Berlin (FUB) and a subsequent postdoctoral year at the University of California, Riverside, I accepted a Professorship at FUB in 1971 and started to build up a rather large research group doing EPR and ENDOR, ODMR and high-field EPR/ENDOR spectroscopy on (bio)organic complexes. Our work has been generously supported over the years, primarily by grants from the DFG (among them several Collaborative Research Centers as well as the Priority Program "High-field EPR"), the VW Foundation (e.g., the Priority Program "Electron Transfer") and several ESF programs (among them INTAS, COST P15).

In the Institute of Molecular Physics of FUB, I was Executive Director from 1987 to 1989 and in the Department of Physics of FUB, I served as Vice Dean and Dean 1991-1993. From 1983 to 1990, I was Confidant Professor of the DFG for the FUB. After formal retirement in 2001, I continue my scientific work at the Department of Physics of FUB. I would like to thank the Department of Physics of the Free University Berlin for this opportunity. From 1998 to 2006, I was Coordinator and Subproject Director of the DFG Priority Program "High-field EPR". I was President of the European Federation of EPR Groups (EF-EPR) 1991-1994, Vice-President for Europe of the International EPR (ESR) Society (IES) 2012-2013, and subsequently elected President of IES for 2013-2014.

I was Visiting Professor at the Hebrew University of Jerusalem (Summer 1980), the Indian Institute of Technology Madras (Winter 1983), the University of Padova (Winter 1997), the Tohoku University, Sendai (Spring 2001). I have been Fellow of Institutes for Advanced Studies at the Hebrew University of Jerusalem (Winter 1990/91) and two times at the University of Bologna (Winter 2009 and Winter 2010). Since 2009 until 2018, I was Guest Scientist at the Max-Planck Institute for Bioinorganic Chemistry (now Institute for Chemical Energy Conversion), in Mülheim (Ruhr) to actively continue our joint research with Prof. Wolfgang Lubitz and Dr. Anton Savitsky. I am very grateful to Wolfgang for all his personal help, his continuing scientific support and constructive criticism-and a wonderful friendship, also with his family.

\section{Awards and Honors}

I received numerous awards and honors, among them: the Karl Scheel Prize of the Berlin Physical Society (1966); DFG Postdoctoral Fellowship (1969/70); BrukerLecturer Award of the Royal Society of Chemistry (1987); Max-Planck-Research Award of the Alexander von Humboldt Foundation (together with Haim Levanon, 1992); Zavoisky Award (together with Jim Norris and Yakov Lebedev, 1994); IES Silver Medal Award (1996); Philip-Morris Research Award (1996); AMPERE 
Award of the European Groupement AMPERE (1998); the Roessler Lecturer Award of the Cornell University (2001); the IES Gold Medal Award (2001); the Voevodsky Award of the Russian Academy of Sciences, Siberian Branch (2006). I was honored by the Cross of Merit First Class (Verdienstkreuz 1. Klasse) of the Federal Republic of Germany (2006) for establishing worldwide sustaining international cooperations. I am Foreign Member of the Academy "Istituto Veneto di Scienze, Lettere ed Arti" in Venice (2002); Fellow of the International Society of Magnetic Resonance (ISMAR) (2009); Fellow of the International EPR/ESR Society (IES) (2011); Foreign Member of the Academy of Sciences of the Republic of Tatarstan (2012). I received the "Medal to the Memory of Academician N.M. Emanuel" Award of the Russian Academy of Sciences and the M.V. Lomonosov University in Moscow for his "Outstanding Results in Chemical and Biochemical Physics" (2019).

\section{Publications}

Over the years, I have reported on our research accomplishments in countless invited lectures at university seminars and international conferences. Since 1963 until 2020, I have coauthored about 360 refereed scientific papers and book chapters. In addition, I have coauthored three books:

Möbius, K., Savitsky, A., High-Field EPR Spectroscopy on Proteins and their Model Systems: Characterization of Transient Paramagnetic States, Royal Society of Chemistry, Cambridge, UK, 2009, pp 1-375.

Möbius, K., Giacometti, G., Life on Earth through Photosynthesis; Dialogues on Key Discoveries and the People Behind Them, Bononia University Press, Bologna, Italy, 2016, pp 1-280.

Möbius, K., Plato, M., Savitsky, A., The Möbius Strip Topology: History, Science and Applications in Nanotechnology, Materials, and the Arts, Jenny Stanford Publishing, Singapore, 2021, in print.

\section{Conclusions}

The results and achievements of my laboratory at FU Berlin would not have been possible without the excellent contributions and dedicated efforts of the members of my research group. By this, I mean the graduate and doctoral students, the postdocs and senior scientists alike-as well as our national and international cooperation partners. To all of them, I express my heartfelt thanks and highest appreciation for their work. I am happy, and actually quite proud, that many former members of my group have remained in science; they have successfully built their own professional careers, whether in academia or Max Planck Institutes, in public research centers or school services, in public patent offices or industrial laboratories for research \& development, in public media and science journalism. Their work is highly recognized and, in many cases, has been distinguished by international awards and honors.

In closing, I would like to thank my wife Uta and our daughters Katharina and Janina for their lasting encouragement and moral support in all my academic and 
private concerns. In addition, I thank them for their empathetic patience with me when my thoughts all too often were drifting off to our experiments-instead of attentively participating in the discussion of current family issues. And this when they had very important things on their minds they wanted to share with me. I am still sorry for this absentmindedness. I regret that I missed many precious moments in our family life because of it. I always knew that I am gifted with a wonderful family.

Funding Open Access funding enabled and organized by Projekt DEAL.

Open Access This article is licensed under a Creative Commons Attribution 4.0 International License, which permits use, sharing, adaptation, distribution and reproduction in any medium or format, as long as you give appropriate credit to the original author(s) and the source, provide a link to the Creative Commons licence, and indicate if changes were made. The images or other third party material in this article are included in the article's Creative Commons licence, unless indicated otherwise in a credit line to the material. If material is not included in the article's Creative Commons licence and your intended use is not permitted by statutory regulation or exceeds the permitted use, you will need to obtain permission directly from the copyright holder. To view a copy of this licence, visit http://creativecommons.org/licen ses/by/4.0/.

\section{References}

1. K. Möbius, Zeitschrift für Naturforschung A 20, 1093-1102 (1965)

2. K. Möbius, Zeitschrift für Naturforschung A 20, 1117-1121 (1965)

3. K. Möbius, H. Van Willigen, A.H. Maki, Mol. Phys. 20, 289-304 (1971)

4. K. Möbius, W. Fröhling, F. Lendzian, W. Lubitz, M. Plato, C.J. Winscom, J. Phys. Chem. 86, 44914507 (1982)

5. K. Möbius, A. Savitsky, High-Field EPR Spectroscopy on Proteins and Their Model Systems: Characterization of Transient Paramagnetic States (RSC Publishing, London, 2009)

6. K. Möbius, D. Goldfarb, High-field/high-frequency electron paramagnetic resonance involving single- and multiple-transition schemes, in Biophysical techniques in photosynthesis. ed. by T.J. Aartsma, J. Matysik (Springer, Dordrecht, 2008), pp. 267-304

7. A.J. Hoff, K. Möbius, Proc. Natl. Acad. Sci. USA 75, 2296 (1978)

8. F. Lendzian, W. Lubitz, H. Scheer, A.J. Hoff, M. Plato, E. Tränkle, K. Möbius, Chem. Phys. Lett. 148, 377-385 (1988)

9. H. Kurreck, M. Huber, Angew. Chem. Int. Ed. 34, 849-866 (1995)

10. H. Levanon, K. Möbius, Annu. Rev. Biophys. Biomol. Struct. 26, 495-540 (1997)

11. J. Fujisawa, K. Ishii, Y. Ohba, S. Yamauchi, M. Fuhs, K. Möbius, J. Phys. Chem. A. 101, 58695876 (1997)

12. F. Lendzian, M. Huber, R.A. Isaacson, B. Endeward, M. Plato, B. Bönigk, K. Möbius, W. Lubitz, G. Feher, Biochim. Biophys. Acta. 1183, 139-160 (1993)

13. A.J. Hoff, J. Deisenhofer, Phys. Rep. 287, 2-247 (1997)

14. H.-J. Steinhoff, A. Savitsky, C. Wegener, M. Pfeiffer, M. Plato, K. Möbius, Biochim. Biophys. Acta. 1457, 253-262 (2000)

15. P. Gast, R.T.L. Herbonnet, J. Klare, A. Nalepa, C. Rickert, D. Stellinga, L. Urban, K. Möbius, A. Savitsky, H.J. Steinhoff, E.J.J. Groenen, Phys. Chem. Chem. Phys. 16, 15910-15916 (2014)

16. K. Möbius, A. Savitsky, M. Malferrari, F. Francia, M.D. Mamedov, A.Y. Semenov, W. Lubitz, G. Venturoli, Appl. Magn. Reson. 51, 773-850 (2020)

17. K. Möbius, M. Plato, G. Klihm, C. Laurich, A. Savitsky, W. Lubitz, B. Szyszko, M. Stepien, L. Latos-Grazynski, Phys. Chem. Chem. Phys. 17, 6644-6652 (2015)

18. K. Möbius, A. Savitsky, W. Lubitz, M. Plato, Appl. Magn. Reson. 47, 757-780 (2016) 
19. K. Möbius, M. Plato, A. Savitsky, The Möbius Strip Topology: History, Science and Applications in Nanotechnology, Materials, and the Arts (Jenny Stanford Publishing, Singapore, 2021)

Publisher's Note Springer Nature remains neutral with regard to jurisdictional claims in published maps and institutional affiliations. 